\title{
Depression, Anxiety and Stress Scale (DASS): The Study of Validity and Reliability
}

\author{
Ertan Basha*, Mehmet Kaya \\ Department of Educational Sciences, Faculty of Education, Sakarya University, Turkey
}

Copyright $(2016$ by authors, all rights reserved. Authors agree that this article remains permanently open access under the terms of the Creative Commons Attribution License 4.0 International License

\begin{abstract}
The purpose of this study is to examine validity and reliability of the Albanian version of the Depression, Anxiety and Stress Scale (DASS), which is developed by Lovibond and Lovibond (1995). The sample of this study is consisted of 555 subjects who were living in Kosovo. The results of confirmatory factor analysis indicated 42 items loaded on three factors (Depression, Anxiety and Stress). As it is shown in the original form, the scale is occurred by three factors. Factor's coefficients were as follows: for the depression .25 to .61 , for anxiety .30 to .53 and for stress .31 to .51 for overall scale. Compliance validation points of DASS were respectively found between .85 and .81 and, 80. Item total correlations were .25 to .61 . Findings demonstrated that Albanian version of DASS has similarity with other researches for reliability and validity scores.
\end{abstract}

Keywords Depression, Anxiety, Stress, Validity, Reliability

\section{Introduction}

Depression derives from the word "depressus" in Latin. The word "Depressus" means pressing down, suffering, exhausted, woeful, sorrowful, discouraged, and deaden. In Turkish, it is used as depression or breakdown (12). Depression is one of the mental disorders that is the most common in young people and causing severe disruptions in psychosocial and academic functioning and that prevents overcoming developmental problems (6). Depression can begin at any age, but the average beginning is in the midtwenties. Epidemiological data show that it has been in an earlier age in recent years (13).

Origin of the word "anxiety" is "anxietas" in Ancient Greek and its meaning is "worry, fear, curiosity" (12). According to Aydemir and Bayraktar; anxiety is a reaction that is unconscious and unknown by person and that occurs against internal threats. In other words, anxiety is a mood, experienced in the face of danger resulting externally (2). Also epidemiological studies reveal that its prevalence in child and adolescent psychiatry is the highest (11).

The word "stress", which comes from 'estrica' in Latin, refers to a warning sign on the health and peace of people, is perceived as a warning and therefore, it represents physiological and psychological reactions that are not distinct towards the poorly addressed events, (21). There are many definitions of stress. In the $18^{\text {th }}$ and $19^{\text {th }}$ centuries, stress was used in meaning of a resistance against distortion with effect of such forces. In addition, stress refers to "keep the integrity" and "make an effort in order to turn basic". Stress is regarded as a situation that shapes the attitudes and behaviors of the individual and the whole environmental, individual and organizational factors to be effective in certain proportions. Stress is a new adaptation effort in the face of threats, challenging in terms of physical and psychological. As stress is a result of external conditions, it can result from perspective of events of individuals. Stress is something that is in the life and also in the structure of people. It is not possible to think about a life full of happy, cheerful and positive conditions by ignoring the sad events (7).

Researches, which were carried out before, assert various models relating to the correlation between depression and anxiety. According to classical theory, anxiety and depression do not differ from each other and sometimes they are syndromes that may exist together. Because tools measuring anxiety and depression contain many common symptoms, results that will be revealed by measurement of these concepts are artefact (All kinds of corruption and impact that not reflect the truth and undesirable on display.) (19).

Due to the correlation between depression and anxiety, some researchers have been prompted to investigation whether the emotional status of these differ from each other. Consequently, some researchers made factor analysis in order to determine discriminant validity of scale items (1). In Beck Depression Inventory, Zung Depression Scale, Costello-Comrey Depression and Anxiety Scale, MMPI Depression Scale, and Rosen Depression Scale, any finding has not been obtained which supports that anxiety and depression are separate factors from each other (16). In confirmatory factor analysis, which was carried out on subjects with depression for Beck Anxiety Scale and Beck Depression Test, results obtained show that a common negative affective factor represents the scale items more 
accurately (8). As a result of the factor analysis, Nelson and Novy have argued anxiety and depression structurally which can be associated with common affective dimension (17). The finding obtained as a result of the factor analysis, has shown the relationship at the middle level between anxiety and stress, although depression, anxiety and stress are different from each other (5).

\section{Depression, Anxiety and Stress Scale (DASS)}

The Depression, Anxiety and Stress Scale were applied in order to reveal the psychological status of the individuals. Also, this scale is used in determining the level of negative emotional states. The scale, developed by Lovibond and Lovibond (1995) and proposed by Australian Psychological Society, has four point Likert scales, consisting of 42 items that examine the level of depression, anxiety and stress of the experimental subject. For each items in the scale, there is a following rating ' 0 ' it is not suitable for me, ' 1 ' it is a little bit suitable for me, '2' it is usually suitable for me, ' 3 ' it is completely suitable for me. Therefore, each participant was requested to mark the most appropriate option for them. And then, it is added for each scale and the depression, anxiety and stress score is calculated. The factor load .36 to .80 for depression, the factor load .31 to. 64 for anxiety and the factor load .40 to .76 for stress are calculated in the explanatory factor analysis for construct validity. The correlation between sub-dimensions is calculated as .38 for depression-anxiety, .46 for anxiety-stress, and .54 for depression-stress. As a result of compliance validity between The Beck Depression Inventory and The Beck Anxiety Inventory, it has been determined that DASS is highly related (respectively .74 and .81) (10). The DASS has been calculated .48 with test-retest reliability coefficient. The Cronbach's Alpha internal consistency coefficients have been determined for depression, anxiety and stress scales respectively $.96, .89$ and .93 . In terms of the number of groups that was carried out for the validity and reliability, it is seemed that they are efficient for statistical analysis. (22).

Table 1. Scoring
\begin{tabular}{|c|c|c|c|}
\hline & Depression & Anxiety & Stress \\
\hline Normal & $0-9$ & $0-7$ & $0-14$ \\
\hline Mild & $10-13$ & $8-9$ & $15-18$ \\
\hline Moderate & $14-20$ & $10-14$ & $19-25$ \\
\hline Severe & $21-27$ & $15-19$ & $26-33$ \\
\hline Extremely Severe & $28+$ & $20+$ & $34+$ \\
\hline
\end{tabular}

Depression, anxiety and stress level ratings were performed as per the table above by the developers of this scale

\section{Method}

\section{Study Group}

This research was carried out between the years 2014 and 2015. The sample of study was composed of individuals, who are elected by random sampling among individuals and who live in different regions of Kosovo. The scope of the study has been obtained by data from 555 people. Of these surveyed, 87 were female and 468 were male.

\section{Process}

In the process of adapting the scale into Albanian, first of all, Lovibond was communicated and the permission that is necessary to adapt the scale was obtained. In the first stage, the English form of the scale was translated into Albanian by a committee consisted of four instructors who are fluent in English. Afterwards, these forms were translated into English again, and the consistency between the Albanian and English forms was examined. And then, the Albanian form was revised by examining in terms of meaning and grammar. Confirmatory factor analysis was used for constructing validity of the scale. According to Büyüköztürk, Confirmatory Factor Analysis (CFA) is used for assessing how much the factors that consist of several variables are in compliance with the actual data. In other words, through a theoretical background in CFA, it is analyzed how much a predetermined or fictionalized structure is confirmed by the data collected (3). In this study, CFA was used to find out the effect of original form of DAS scale on Albanian people and to analyze if the factor of original form confirms the research that was conducted on Albanian people. The reliability of the scale was analyzed with the internal consistency method, and the item analyze was determined with the corrected total item correlation. The data obtained after applying the scale were analyzed by SPSS' 20.

\section{The Process of Translation}

Between validity and reliability analysis in the translation process, the consistency between the Albanian and the English forms were examined by psychologist and three instructors from department of English. And then, the Albanian form was revised by examining in terms of meaning and grammar.

\section{Findings and Interpretation}

\section{Reliability and Item Analysis}

Table 2. Total Correlation Findings in relation to the items of the DASS

\begin{tabular}{|c|c|c|c|c|c|}
\hline \multicolumn{5}{|c|}{ Results of the exploratory and confirmatory analyses of the DASS } \\
\hline Item Number & rjx & Item Number & rjx & Item Number & rjx \\
\hline 3 & .25 & 2 & .41 & 1 & .32 \\
5 & .46 & 4 & .46 & 6 & .34 \\
10 & .49 & 7 & .47 & 8 & .46 \\
13 & .59 & 9 & .30 & 11 & .44 \\
16 & .61 & 15 & .53 & 12 & .51 \\
17 & .58 & 19 & .47 & 14 & .46 \\
21 & .55 & 20 & .49 & 18 & .40 \\
24 & .52 & 23 & .50 & 22 & .50 \\
26 & .58 & 25 & .51 & 27 & .50 \\
31 & .49 & 28 & .43 & 29 & .56 \\
34 & .55 & 30 & .47 & 32 & .35 \\
37 & .51 & 36 & .39 & 33 & .49 \\
38 & .54 & 40 & .33 & 35 & .35 \\
42 & .40 & 41 & .49 & 39 & .34 \\
\hline
\end{tabular}

Internal consistency coefficients of the Albanian form of 
the scale are .85 for depression, .81 for anxiety and .80 for stress. Item analysis was made in order to determine the ability to distinguish the items. As a result of the analysis, the scale of the corrected item-total correlation coefficients showed that it ranged from .25 to .61 . Results have been shown in the Table 2.

\section{Construct Validity}

Confirmatory Factor Analysis. First-level confirmatory factor analysis was performed for construct validity of the Albanian form of the DASS in order to verify the original form of the scale in all the factors. Obtained value of fit index $\left(x^{2}=2292.34, d f=814, \mathrm{RMSEA}=.057\right)$ has shown to fit three-dimensional depression, anxiety and stress towards model of the attitude. In relation to confirmatory factor analysis, the load factors have been shown in the Figure 1.

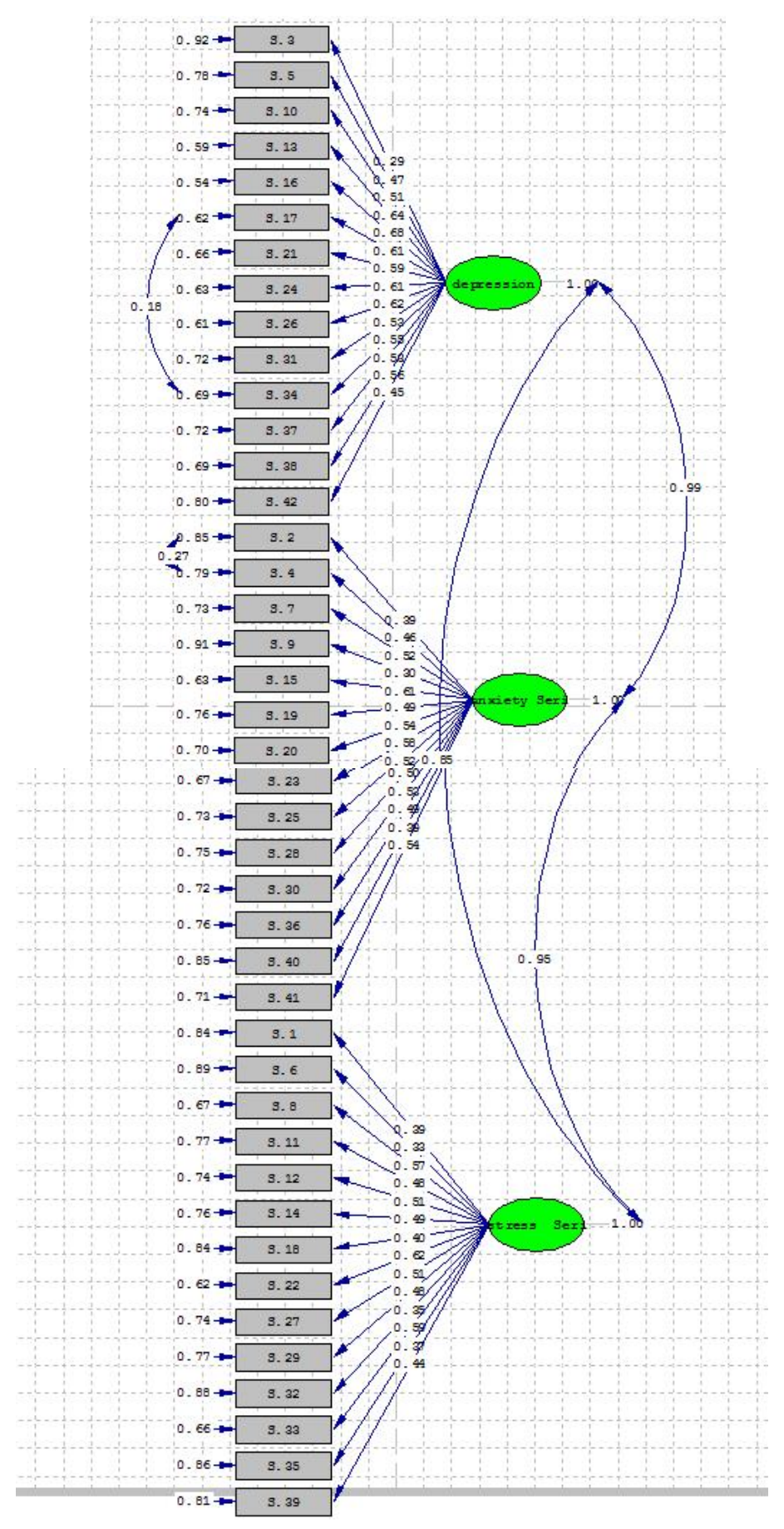

Chi-Scuare=2292.34. df=814. P-value=0.00000. RMSEA=0.057

Figure 1. Confirmatory Factor Analysis for the Depression Anxiety and Stress Scale. 


\section{Discussion}

The aim of this study is to adapt to the Albanian Depression, Anxiety and Stress Scale and to make validity and reliability studies of the Albanian version. In the scope of the study, data have been obtained from 555 people. It has been thought to be sufficient of the sample group of the study in terms of number. As a result of the analysis for factor load yield was as follows: .25 to .61 for depression, .30 to .53 for anxiety, .31 to .51 for stress. These results have showed that items are to be appropriate to the original form. In other words, all these results have showed that the Albanian form of DASS has validity at a high level.

According to the results of the SPSS analysis, as shown in figure 1, the value of fit index for the depression and anxiety dimensions has been applied and rehabilitated. Also Turkish resources that support this matter have been found.

According to the results of the item analysis, the total item correlation score of the scale has been yielded to be .25 to .61. According to Greca et al. kept out items were beneath .30. Also Tavşancil has suggested that it should be .30 and over. Büyüköztürk has stated that the total item correlation score of the items should be over .30. According to Özdamar, the total item correlation should be related to each other in a certain level rather than in a high or low level. If the higher items are in an appropriate level, they can be considered as sufficient. As it is mentioned above, by considering the researches, no item has been removed from the scale. These results have revealed that Cronbach Alpha coefficient for depression is .85 , for anxiety .81 and for stress .80 . Therefore, all items in the scale are consistent with each other and the reliability of the scale is high (9-234-18).

Chi-square test $\left(x^{2}\right), x^{2} / s d$, RMSEA, RMR, GFI and AGFI are used the most often with confirmatory factor analysis related to the model data fit calculated for statistics. As a result of the analysis, .57 for the RMSEA, .47 for the RMR, .84 for the GFI and .82 for the AGFI have been calculated. If $\mathrm{x}^{2}$ rate is smaller than 5, and GFI and AGFI rates are higher than .90 , and SRMR rate is smaller than .05 , then it has the model data fit (14). However, if GFI is greater than .85 and AGF is greater than .80 and RMSEA is less than .10, they are acceptable for the model data fit (15). Reliability level of the measurement tools which can be used in studies if it takes into consideration to be .70 , scale of the Albanian form will provide for reliability. The finding, obtained from the validity and reliability of the Albanian form of scale has shown that it is ready for use and it can be used with validity and safely to determine depression, anxiety and stress levels of individuals. In addition, it would be useful to investigate with factor such as depression, anxiety and stress. Finally, the scale would be useful to be used by other researchers. Also, thanks to the conducted research, it will contribute to DASS.

\section{Conclusions and Recommendations}

The finding obtained from analysis of the validity and reliability of the Depression, Anxiety and Stress Albanian Form (DAS-AF) has showed that it is ready for use. This study was carried out on individuals that live in Kosovo. Therefore, it should be carried out on different groups for validity and reliability of the DAS-AF. In addition, examination of the test-re-test the validity and reliability of the scale is proposed to other researchers. Finally, in order to determine the compliance validity of the scale, different scales, which prove the validity and reliability, The Depression, Anxiety and Stress Scale can be examined.

\section{REFERENCES}

[1] Akın, A. ve Cetin, B. (2007). Depresyon, Anksiyete, Stres Ölçeği (DASÖ): Geçerlik ve Güvenirlik Çalışması. Kuram ve Uygulamada Eğitim Bilimleri,7 (1), 241-268.

[2] Aydemir, Ö. ve Bayraktar, E. (1996). Genel Tipta Anksiyete (II) PsychoMed, 2(4):134-140.

[3] Büyüköztürk, Ş. (2004). Veri Analizi El Kitabı. Ankara: Pegem A Yayıncilik.

[4] Büyüköztürk, Ş.(2007). Sosyal Bilimler İçin Veri Analizi El Kitabı, Ankara: Pegem A Yayıncılık.

[5] Brown, T. A., Chorpita, B. F., Korotittsch, W., \& Barlow, D. H. (1997). Psychometric Properties of the Depression Anxiety Stress Scale (DASS) in Clinical Samples. Behavior Research and Therapy, 35, 79-89.

[6] Canat, S. (1997). Ergenlerde Depresyon. Ege Psikiyatri Sürekli Yayınları; Ege Psikiyatri Derneği Yayın Organı, 2: 469-472.

[7] Demir, A., H. (2002). "İlköğretim Öğrencilerinde Stres Yaratan Yönetici Davranışları ve Öğrencilerin Başa Çıkma Davranışları”, Ankara Üniversitesi Eğitim Bilimleri Enstitüsü, Yayınlanmamış Yüksek Lisans Tezi, Ankara.

[8] Enns, M. W., Cox, B. J., Parker, J., \& Guertin, J. E. (1998). Confirmatory Factor Analysis of the Beck Anxiety and Depression Inventories in Patients with Major Depression. Journal of Affective Disorders, 47, 195-200.

[9] Greca,M.A., Dandes,K.S., Wick,P., Shaw,K\& Stone,L.W. (1998), Development of the Social Anxiety Scale for Children: Reliability and Concurrent Validity, Journal of Clinical Child Psychology, 17(1), 84-91.

[10] Lovibond, S. H., \& Lovibond, P. F. (1995b). Manual for the Depression Anxiety Stress Scale. Sydney: The Psychological Foundation of Australia, Inc.

[11] Kashani, J.H., Orvaschel, H. (1990). A Community Study of Anxiety in Children and Adolescents. Am J Psychiatry, 147: 313-318.

[12] Köknel, Ö. (1988). Zorlanan İnsan. İstanbul; Altın Kitaplar Yayınevi, 2. Basım. 
[13] Köroğlu, E. (1997). Majör Depresif Bozukluk. Psikiyatri Temel Kitabı, Cilt 1, Ed: C. Ankara, Hekimler Yayın Birliği, s.389- 421.

[14] Marsh, H. W., \& Hocevar, D. (1988). A New More Powerful Approach to Multi Trait - Multi Method Analyses: Application of Second - Order Confirmatory Factor Analysis. Journal of Applied Psychology, 73, 107 - 117.

[15] Marsh, H. W., Balla, J. R., \& Mcdonald, R. P. (1988). Goodness-of-Fit Indexes in Confirmatory Factor Analysis: The Effect of Sample Size. Psychological Bulletin, 103, 391410.

[16] Mendels, J., Weinstein, N., \& Cochrane, C. (1972). The Relationship between Depression and Anxiety. Archives of General Psychiatry, 27, 649-653.

[17] Nelson, D. V., \& Novy, D. M. (1997). Self-Rapport Differentiation of Anxiety and Depression in Chronic Pain.
Journal of Personality Assessment, 69 (2), 392-407,

[18] Özdamar, K. (2002). Paket Programlar ile İstatistiksel Veri Analizi. Kaan Yayınları, 4. Baskı, Eskişehir.

[19] Seligman L, Ollendick T, (1998). Comorbidity of Anxiety and Depression in Children and Adolescents: An İntegrative Review. Clinical Child and Family Psychology Review.

[20] Sipahi, B., Yurtkoru, E. S. \& Cinko, M. (2008). Sosyal Bilimlerde SPSS'le Veri Analizi. İstanbul: Beta Basım Yayım Dağıtım.

[21] Şenyiğit, G. (2004). "Çalışma Hayatında Stres", Verimlilik Dergisi, Ankara, MPM Yayını, Temmuz, s.104.

[22] Tabachnick, B. G., \& Fidell, L. S. (2007). Using Multivariate Statistics. Boston: Allyn and Bacon.

[23] Tavşancıl, E. (2002), Tutumların Ölçülmesi ve SPSS ile Veri Analizi, Ankara: Nobel. 